\title{
PENGARUH JOB STRESS DAN JOB SATISFACTION TERHADAP PSYCHOLOGICAL WELL-BEING
}

\author{
Fellia Sakti Dewi Washinta \\ Universitas Negeri Surabaya \\ fellia.17080574126@mhs.unesa.ac.id \\ Hafid Kholidi Hadi \\ Universitas Negeri Surabaya \\ hafidhadi@unesa.ac.id
}

\begin{abstract}
This study aims to analyze the effect of job stress and job satisfaction on the psychological well-being of postgraduate employees at the State Islamic University of Sunan Ampel Surabaya. This research method uses quantitative research, with the method used in sampling is saturated sampling. The population used is 41 employees. The analysis of this study using Multiple Linear Regression Analysis by IBM SPSS Statistics 24.0 software. This study concluded that job stress has a negative and meaningful effect on psychological well-being because the burden of many tasks results in stress that causes psychological well-being to decrease. For job satisfaction has a positive and meaningful effect on psychological well-being, the lack of employees results in dissatisfaction when doing work that affects psychological well-being. Meanwhile, the meaningful effect of job stress and job satisfaction on psychological well-being occurs because the simultaneous significance test ( $f$ test) are overall Ho is accepted. Institutions must pay attention to work stress experienced by their employees so that the psychological well-being of employees can be well maintained and will have a good impact on employee job satisfaction.
\end{abstract}

Keywords: job satisfaction; job stress; psychological well-being.

\section{PENDAHULUAN}

Di era industri 4.0 banyak organisasi berdiri di Indonesia. Akibatnya masing-masing orang bersaing untuk bekerja di instansi yang mereka impikan sejak di bangku perkuliahan, dan di antaranya perusahaan yang berfokus di bidang jasa dan manufaktur (Tasema, 2018). Menurut Hasibuan (2003) seseorang harus bekerja karena merupakan suatu kebiasaan sehari-hari yang dikerjakan setiap manusia. Hal tersebut bertujuan untuk memenuhi kebutuhan hidupnya dan memenuhi kebutuhan sumber daya manusia di perusahaan. Menurut As'ad (2015), alasan yang memengaruhi manusia untuk bekerja adalah adanya keinginan yang belum tercapai, dengan bekerja mereka bisa mencapai kehidupan yang lebih baik misalnya dapat membeli pakaian, makanan dan tempat tinggal sehingga seseorang dapat hidup aman dan bahagia. Ketika aman, bahagia, dan sejahtera dapat dimiliki seseorang yakni mereka akan memeroleh jasmani maupun rohani yang baik, serta dapat memenuhi kebutuhan ekonomi keluarga dengan cara memeroleh penghasilan tetap, dan seseorang bisa meningkatkan kedudukan keluarga di mata masyarakat.

Menurut Devonish (2016), kesejahteraan psikologis merupakan sebuah upaya untuk meraih suatu kemampuan dalam diri seseorang secara psikologis dan ketika seseorang bisa menerima kelebihan dan kekurangan pada dirinya, memiliki tujuan hidup, dengan rekan kerja mereka dapat menumbuhkan hubungan yang baik, menjadi individu yang senantiasa berkembang, dapat mengontrol sekitarnya, serta memiliki sikap mandiri. Momen seorang individu akan menunjukkan kinerja yang optimal dan merasa bahagia ketika mereka memandang suasana kerja sebagai suasana yang menantang, menyenangkan, serta menarik. Menurut Malek et al. (2010), ketika tingkat stres seseorang meningkat, dapat mengakibatkan turunnya kesejahteraan psikologis seseorang.

Berdasarkan studi terdahulu, ditemukan aspek-aspek yang memberikan pengaruh psychological wellbeing bagi individu, contohnya budaya organisasi (Prilianti et al., 2021), work family conflict (Anggarwati \& Thamrin, 2020), kecerdasan emosi (Sirait, 2020), stres kerja (Issom \& Raisata, 2017) 
dan kepuasan kerja (Tasema, 2018). Menurut Issom \& Raisata (2017), penting sekali untuk dapat mengetahui kesejahteraan psikologis, agar seseorang bisa melakukan kehidupannya secara aman dan tentram, bahagia, dan dapat mengatasi bermacam persoalan yang timbul, sehingga ketika sebuah masalah terjadi dalam kehidupan seseorang maka bisa memicu terjadinya stres pada seseorang. Stres ini bisa dialami oleh siapapun, semua ini tergantung dengan dorongan yang bisa menimbulkan, hasil yang disebut dengan stressor. Menurut Hamaideh (2011), stessor didefinisikan sebagai tuntutan yang berasal dari internal maupun eksternal mengenai seseorang, hal ini dapat menimbulkan terjadinya psychological well-being pada individu. Menurut Robbins \& Timothy (2016), job stress merupakan sebuah kondisi yang dinamik di tempat kerja di mana seseorang itu diharapkan dengan tuntutan, keterbatasan, sesuai dengan output dan ekspektasi yang diinginkan oleh individu itu sendiri untuk mencapai suatu hal dalam ketidakpastiaan serta situasi genting.

Robbins (2002) menyatakan ada tiga dimensi yang membangun job stress seseorang di antaranya yaitu gejala psikologis yang muncul karena stres di antaranya adalah adanya ketidakpuasan hubungan kerja, cemas, gelisah, ketegangan, dan mudah marah. Gejala fisiologis yang berkaitan dengan aspek kesehatan, dan medis seperti adanya perubahan metabolisme pada badan, meningkatkan tekanan darah, dan timbulnya sakit kepala. Gejala perilaku yang mencakup perubahan seseorang di antaranya adalah adanya berubahan selera makan, susah tidur, serta meningkatnya konsumsi alkohol dan rokok. Dilihat dari dimensi-dimensi, gejala psikologis termasuk salah satu dimensi job stress. Maka kesejahteraan psikologis merupakan sebuah alasan yang mengakibatkan terjadinya job stress pada pegawai.

Hasil penelitian Lee \& Kim (2012) membuktikan adanya pengaruh positif kepemimpinan transformasional terhadap modal psikologis positif, kesejahteraan psikologis dan berpengaruh negatif terhadap stres di Rumah Sakit Umum berlokasi di Kota G dan B. Menurut Nzenweaku et al. (2020), ketika wanita stres dan tanpa dukungan yang cukup di tempat kerja atau di rumah, mereka akan cenderung memiliki kesejahteraan psikologis yang buruk ini terjadi di Nigeria. Menurut Anggraeni \& Jannah (2014), membuktikan bahwa ada pengaruh yang signifikan antara kesejahteraan psikologis dan kepribadian hardiness dengan stres pada petugas port security di Pelabuhan Tanjung Perak Surabaya.

Kepuasan kerja (job satisfaction) merupakan perihal positif dari tanggapan mengenai profesi seseorang yang ditimbulkan oleh penilaian pekerjaannya, di mana individu mempunyai kepuasan kerja yang baik maka akan mempunyai tanggapan yang baik akan profesinya (Robbins \& Judge, 2018). Menurut As'ad (2015), rasa puas dalam bekerja dianggap sebagai suatu tanggapan yang baik dan berkaitan dengan adaptasi yang sesuai dari pekerja atas keadaan maupun lingkungan kerjanya. Penyesuaian ini menyangkut masalah keuangan, status sosial, keadaan psikologis maupun fisik. Martoyo (2007) menyatakan kepuasan kerja dapat dilihat dengan unsur psikologis yang menggambarkan tanggapan individu atas profesinya, di mana mereka akan merasakan kepuasan atas hasil yang diharapkan pada tanggung jawab yang dimiliki.

Menurut Nandoliya (2017), psychological well-being berdampak positif dan signifikan terhadap job satisfaction di Sekolah Menengah Atas binaan Pemerintah dan Swasta. Muniandy (2017) membuktikan kepuasan kerja para guru tidak dipegaruhi oleh kesejahteraan psikologis di salah satu Universitas Negeri di Malaysia. Menurut Drakopoulos \& Grimani (2015), pemotongan gaji berdampak signifikan negatif terhadap psychological well-being dan juga terhadap kepuasan kerja di negara-negara Eropa. Martynowska et al. (2020) mengatakan bahwa dampak negatif berhubungan dengan perceived stress yang dirasakan, kemudian dikaitkan dengan psychological well-being and life satisfaction.

Menurut hasil wawancara dengan pegawai Pascasarjana Univesrsitas Islam Negeri Sunan Ampel Surabaya. Pegawai memiliki job stress yang buruk, karena adanya kebutuhan pegawai yang biasanya tidak diperhatikan, padahal tanggung jawab sebagai pegawai cukup banyak. Contohnya pegawai umumnya menjadi sumber ketegangan dikarenakan lingkungan serta situasi kerja yang terlampau berat dengan beban tanggung jawab birokrasi serta kurangnya pegawai yang bekerja.

Narasumber mengatakan bahwa pegawai kurang dalam job satisfaction yakni pegawai tidak dapat bekerja secara optimal dan mempunyai perasaan ketidakpuasan dengan pekerjaannya, hal ini 
menandakan gaji yang didapatkan belum cukup oleh pegawai karena terkadang pegawai menyelesaikan tugas-tugas mereka yang di luar job description. Selain itu, ketidakpuasan bekerja timbul akibat kurangnya tunjangan tambahan misalnya, liburan bersama dengan keluarga para pegawai dan voucher berbelanja untuk pegawai yang telah memberikan kinerja terbaik pada perusahaan. Dengan demikian, sebaiknya seorang pemimpin selalu memberikan psychological well-being kepada pegawai, di mana dari contoh indikator psychological well-being yakni hubungan positif dengan orang lain, menurut pegawai bahwa orang-orang yang berada di kantor sangat mengutamakan relasi interpersonal, saling percaya, serta menjalin keakraban antar pegawai lain.

Dari fenomena gap dan paparan riset gap di atas, maka penelitian ini bertujuan untuk menganalisis bagaimana pengaruh job stress dan job satisfaction terhadap psychological well-being pada pegawai Pascasarjana Universitas Islam Negeri Sunan Ampel Surabaya.

\section{KAJIAN PUSTAKA DAN PENGEMBANGAN HIPOTESIS}

\section{Job Stress}

Menurut Machado et al. (2019), job stress ditunjukkan dengan suatu reaksi tubuh dan penuh dengan emosi yang dapat membahayakan psikologis seseorang, jika peraturan yang sudah dibuat dari perusahaan tidak cocok dengan keahlian yang dimiliki, maka keinginan para pegawai dan sumber dayanya akan saling berkaitan. Hal tersebut sesuai dengan pernyataan Soteriades et al. (2019) bahwa stres kerja timbul ketika seseorang merasakan tertekan dalam pekerjaannya yang tidak sebanding dengan kemampuan ataupun pengetahuan yang dikuasainya. Vanchapo (2020) menjelaskan job stress adalah suatu bagian dari kegiatan individu yang dilaksanakan setiap hari dapat menimbulkan reaksi emosional disebabkan oleh ketidaksesuaian beban kerja dengan kemampuan diri sendiri dalam menghadapi stres contohnya, ketika seorang wanita yang sudah berumah tangga mereka akan mengalami stres dalam mengatur urusan rumah, pelajar yang mengalami stres yang disebabkan oleh pelajaran yang tidak bisa dikuasainya, seperti halnya mengenai pengusaha dan orang yang bekerja di perusahaan.

Ada tiga indikator stres kerja yakni gejala psikologis, pengaruh awal stres biasanya munculnya ketika ketidakpuasan dengan pekerjaan yang mereka lakukan di antaranya adalah cemas, gelisah, ketegangan, mudah marah, sering menunda pekerjaan dan kebosanan; Kedua adalah gejala fisiologis, yang berkaitan dengan aspek kesehatan dan medis yang di antaranya adalah perubahan metabolisme pada badan, meningkatkan tekanan darah dan timbulnya sakit kepala; Ketiga merupakan gejala perilaku, yang mencakup perubahan seseorang di antaranya adalah adanya perubahan selerah makan, gelisah, berbicara dengan intonasi cepat dan susah tidur (Robbins, 2002).

\section{Job Satisfaction}

Menurut Lantara \& Nusran (2019), kepuasan kerja adalah sebuah perilaku yang menyenangkan berakibat positif dalam diri seseorang terhadap pekerjaannya yang dapat menimbulkan penilaian terhadap situasi kerja sesuai dengan aspek pekerjaannya sehingga seseorang dapat relatif puas dengan salah satu aspek dan tidak puas dengan aspek lainnya. Menurut Fattah (2017), job satisfaction adalah semakin banyak aspek-sapek dalam pekerjaan yang setara dengan harapan seseorang pada organisasi maka semakin tinggi tingkat kepuasan yang dirasakannya, sebaliknya jika semakin sedikit aspek dalam perusahaan yang setara dengan harapan seseorang pada perusahaan maka semakin rendah tingkat kepuasan yang dirasakan. Robbins \& Judge (2018) mengemukakan bahwa rasa puas dalam kerja adalah suatu keterlibatan pekerjaan, tingkat di mana orang mengidentifikasi secara psikologis dengan pekerjaan mereka dan menganggap tingkat kinerja yang dianggap itu penting bagi harga diri mereka untuk mencapai tujuan yang ditetapkan oleh perusahaan. Ada sembilan indikator job satisfaction yakni komunikasi, sifat kerja, rekan kerja, kebijakan serta metode kerja, apresiasi dari instansi, tunjangan, atasan, kesempatan kenaikan jabatan, serta gaji (Spector, 1997).

\section{Psychological Well-Being}


Fellia Sakti Dewi Washinta \& Hafid Kholidi Hadi. Pengaruh Job Stress dan Job Satisfaction terhadap Psychological Well-Being

Cardak (2013) menjelaskan kesejahteraan psikologis diartikan sebagai struktur yang bermula dari pikiran dalam diri sendiri guna menumbuhkan rasa percaya diri seseorang agar mampu untuk merasakan kebahagiaan. Ramadhani et al. (2016) menunjukkan bahwa psychological well-being sebagai fungsi positif pada diri individu, di mana fungsi positif tersebut merupakan arah dan tujuan yang harus diusahakan oleh individu yang sehat untuk segera dicapai. Keadaan ini dikemukakan Ryff (2014) bahwa seseorang yang dianggap baik secara mental atau psikisnya mereka adalah manusia yang terbebas dari aspek-aspek kesehatan psikologis yang bersifat negatif seperti terdapat rasa cemas dan ketakutan yang membuat seseorang tidak bisa tercapainya perasaan bahagia dan lain sebagainya. Ada enam indikator psychological well-being menurut Ryff (2014), antara lain self acceptance, positive relation with others, otonomi, environmental mastery, tujuan hidup, pertumbuhan personal.

\section{Hubungan antar Variabel}

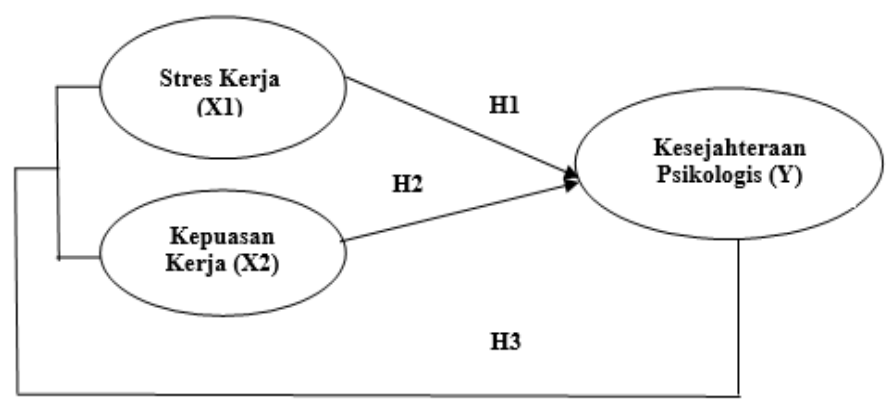

Gambar 1. KERANGKA KONSEPTUAL

Issom \& Raisata (2017) menyatakan job stress berpengaruh negatif terhadap psychological well-being. Leong \& Malek (2020) mengemukakan stres kerja memiliki pengaruh negatif terhadap psychological well-being. Sedangkan Jasmani \& Jumaat (2011) menggambarkan stress berpengaruh signifikan terhadap psychological well-being pada pemerintah di Malaysia.

H1 : Stres kerja berpengaruh negatif dan signifikan terhadap kesejahteraan psikologis pada pegawai Pascasarjana UIN Sunan Ampel Surabaya.

Tasema (2018) mengemukakan bahwa kepuasan kerja pengaruh positif terhadap psychological wellbeing. Yücel (2016) dalam penelitiannya juga menemukan bahwa terdapat hubungan yang positif antara tingkat kesejahteraan psikologis maupun tingkat kepuasan kerja. Hasil ini didukung oleh Karima \& Baidun (2019) sesungguhnya kesejahteraan psikologis berhubungan positif dengan rasa puas dalam bekerja.

H2 : Kepuasan kerja berpengaruh positif dan signifikan terhadap kesejahteraan psikologis pada pegawai Pascasarjana UIN Sunan Ampel Surabaya.

Chitra (2021) menemukan bahwa terdapat pengaruh positif dalam hubungan stres kerja dan kepuasan kerja terhadap psychological well-being. Akan tetapi hasil berbeda dikemukakan Martynowska et al. (2020) ditemukan adanya pengaruh negatif yang diberikan oleh perceived stress terhadap variabel psychological well-being and life satisfaction.

H3 : Stres kerja dan kepuasan kerja berpengaruh signifikan terhadap kesejahteraan psikologis pada pegawai Pascasarjana UIN Sunan Ampel Surabaya.

\section{METODE PENELITIAN}

Jenis penelitian ini adalah kuantitatif. Objek penelitian di Pascasarjana UIN Sunan Ampel Surabaya. Populasi yang digunakan sebanyak 41 pegawai Pascasarjana UIN Sunan Ampel Surabaya. Teknik pengambilan sampel yakni sampling jenuh. Variabel yang dipakai adalah variabel bebas yaitu stres 
kerja (X1) dan kepuasan kerja (X2). Variabel terikat yakni kesejahteraan psikologis (Y). Indikator stres kerja mengacu pada Robbins (2002) terdiri dari 3 indikator. Indikator kepuasan kerja mengacu pada Spector (1997) terdiri dari 9 indikator. Indikator kesejahteraan psikologis merujuk pada Ryff (2014) terdiri dari 6 indikator. Metode perolehan data melalui wawancara dan menyebarkan kuesioner kepada pegawai. Penelitian ini menggunakan skala Likert, range 1 hingga 5 yaitu sangat tidak setuju (STS), tidak setuju (TS), netral (N), setuju (S), dan sangat setuju (SS). Teknik analisis data menggunakan analisis regresi linier berganda dengan software IBM SPSS Statistics Base 24.0.

\section{HASIL DAN PEMBAHASAN}

\section{Hasil Uji Validitas dan Uji Reliabilitas}

Uji validitas instrumen dilakukan dengan menyebarkan kuesioner kepada 41 partisipan. Jumlah pertanyaan yang ada di kuesioner berjumlah 30 item pertanyaan yakni stres kerja berjumlah 6 pertanyaan, kepuasan kerja berjumlah 18, dan kesejahteraan psikologis berjumlah 6 pertanyaan. Hasil pengujian dari 30 item pertanyaan mempunyai nilai $r$ hitung (koefisien korelasi) $>r$ tabel (nilai kritis) dengan taraf signifikansi 5\%, sehingga dinyatakan valid (Ghozali, 2016) dan dapat digunakan untuk melakukan pengukuran pengaruh stres kerja dan kepuasan kerja pada kesejahteraan psikologis.

Uji reliabilitas dinyatakan reliabel jika nilai cronbach's alpha> 0,60 (Sugiyono, 2018). Hasil pengujian menunjukkan nilai cronbach's alpha variabel stres kerja sebesar 0,702, variabel kepuasan kerja sebesar 0,869, dan variabel kesejahteraan psikologis sebesar 0,700. Hasil uji reliabilitas, seluruh variabel memiliki nilai cronbach's alpha lebih dari 0,60. Jadi instrumen penelitian adalah reliabel.

\section{Hasil Uji Asumsi Klasik}

Tabel 1.

HASIL UJI REGRESI

\begin{tabular}{lccccc}
\hline Model & $\mathbf{R}$ & $\boldsymbol{R}$ Square & Adjusted R Square & $\begin{array}{c}\text { Std. Error of the } \\
\text { Estimate }\end{array}$ & Durbin-Watson \\
\hline 1 & $.842^{\mathrm{a}}$ & .710 & .694 & 1.497 & 2.097 \\
a. Predictors: (Constant) Job Satisfaction $(X 2)$, Job Stress (X1) & \\
b. Dependent Variable: Psychological Well-Being $(Y)$ & & \\
\hline
\end{tabular}

Sumber: Output SPSS 24 (2021)

Berdasarkan tabel 1, koefisien determinasi (adjusted $R$ square) sebesar 0,694 yang menunjukkan variabel kesejahteraan psikologis (Y) dipengaruhi oleh variabel stres kerja (X1) dan kepuasan kerja (X2) sebesar 69,4\% sedangkan sisanya 30,6\% dipengaruhi variabel lain di luar penelitian.

Tabel 2.

Hasil Uji SIGNIFIKANSI SIMULTAN (Uji F)

\begin{tabular}{lcccccc}
\hline Model & Sum of Squares & Df & Mean Square & F & Sig. \\
\hline 1 & Regression & 208.354 & 2 & 104.177 & 46.460 & $.000^{\mathrm{b}}$ \\
& Residual & 85.207 & 38 & 2.242 & \\
Total & 293.561 & 40 & & \\
\multicolumn{6}{l}{ a. Dependent Variable: Psychological } & Well-Being (Y) \\
b. Predictors: (Constant), Job Satisfaction (X2), Job Stress (X1) \\
\hline
\end{tabular}

Sumber: Output SPSS 24 (2021)

Berdasarkan tabel 2 nilai signifikansi adalah 0,000, sehingga dapat dinyatakan jika variabel stres kerja (X1) dan kepuasan kerja (X2) berpengaruh secara simultan terhadap variabel kesejahteraan psikologis (Y) atau Ho diterima dan Ha ditolak. Dari analisis tersebut, variabel stres kerja dan kepuasan kerja berpengaruh signifikan terhadap variabel psychological well-being. 
Fellia Sakti Dewi Washinta \& Hafid Kholidi Hadi. Pengaruh Job Stress dan Job Satisfaction terhadap Psychological Well-Being

Tabel 3.

HASIL UJI ANALISIS REGRESI

\begin{tabular}{ccccccccc}
\hline \multicolumn{1}{l}{ Model } & & B & Std. Error & Beta & T & \multicolumn{2}{c}{ Sig. Tolerance } & VIF \\
\hline 1 & (Constant) & 8.680 & 3.497 & & 2.482 & .018 & & \\
& X1 & -.258 & .098 & -.272 & -2.621 & .013 & .708 & 1.413 \\
& X2 & .263 & .041 & .664 & 6.388 & .000 & .708 & 1.413
\end{tabular}

a. Dependent Variable: Psychological Well-Being (Y)

Sumber: Output SPSS 24 (2021)

Menurut Ghozali (2016) hasil perhitungan uji signifikansi parsial berfungsi untuk melihat apakah ada pengaruh signifikan atau tidak dari variabel bebas secara parsial pada variabel terikat. Menurut pengujian parsial pada tabel 3, nilai sig. variabel stres kerja adalah $0,013<0,05$ dan diperoleh t-tabel adalah - 2.02439, jadi hipotesis nol diterima, artinya variabel stres kerja (X1) berpengaruh negatif dan signifikan terhadap variabel kesejahteraan psikologis (Y) pada Pascasarjana UIN Sunan Ampel Surabaya. Nilai sig. variabel kepuasan kerja sebesar $0,000<0,05(\operatorname{sig}<\alpha=0,000<0,05)$ dan t-hitung 6,388 melebihi t-tabel 2.02439, jadi hipotesis nol ditolak artinya variabel kepuasan kerja (X2) memengaruhi variabel kesejahteraan psikologis (Y) pada Pascasarjana UIN Sunan Ampel Surabaya.

\section{Pengaruh Job Stress terhadap Psychological Well-Being}

Berdasarkan hasil penelitian pada pegawai menunjukkan terdapat pengaruh negatif dan signifikan yang dihasilkan, maka dapat dijelaskan bahwasannya bertambah tinggi kenaikan stres kerja sampai berkurang pula kesejahteraan psikologis dari pegawai Pascasarjana UIN Sunan Ampel Surabaya. Dari penelitian tersebut jika dikaitkan dengan hasil wawancara kepada beberapa pegawai di Pascasarjana UIN Sunan Ampel Surabaya menyatakan bahwa kantor pusat kurang memerhatikan kehidupan pegawai untuk kesejahteraaan psikologis para pegawai akan tetapi sudah beberapa kali meminta untuk pertambahan pegawai tidak ada jawaban oleh kantor pusat, karena pada saat pegawai di Pascasarjana menginginkan adanya pertambahan pegawai yang disebabkan oleh beban tugas yang terlalu banyak dan jumlah pegawai yang terlampau sedikit. Hal ini membuat karyawan tidak dapat berkerja dengan baik dan akan berdampak pada mogok kerja. Hasil studi ini diperkuat oleh Oktaviani \& Suprapti (2021).

\section{Pengaruh Job Satisfaction terhadap Psychological Well-Being}

Berdasarkan hasil penelitian pada pegawai menunjukkan terdapat pengaruh positif dan signifikan yang dihasilkan. Selaras dengan penelitian Nandoliya (2017) bahwa job satisfaction berpengaruh positif dan signifikan terhadap psychological well-being. Maka dapat dikatakan semakin tinggi kepuasan kerja yang diakibatkan bertambah tinggi pula kenaikan kesejahteraan psikologis yang akan didapatkan pegawai dan kebalikannya kepuasan kerja yang rendah akan menurunkan level kesejahteraan psikologis. Dari penelitian tersebut jika dikaitkan dengan hasil wawancara kepada beberapa pegawai di Pascasarjana UIN Sunan Ampel Surabaya menyatakan bahwa kepuasan kerja ini terjadi karena kurangnya pegawai yang bekerja disana mengakibatkan kualitas menurun maupun tidak profesional dalam bekerja dan ketidakpuasan sama profesinya. Namun pegawai juga tidak mendapatkan tunjangan tambahan dari instansi. Temuan studi ini diperkuat dengan pendapat yang dilaksanakan oleh Quilim et al. (2016).

\section{Pengaruh Job Stress dan Job Satisfaction terhadap Psychological Well-Being}

Berdasarkan hasil riset pada pegawai menunjukkan terdapat pengaruh secara signifikan yang dihasilkan. Ketika stres kerja dan kepuasan kerja memberi pengaruh terhadap kesejahteraan psikologis pada pegawai Pascasarjana UIN Sunan Ampel Surabaya. Dalam riset ini jika dikaitkan dengan hasil wawancara kepada beberapa pegawai yang berada di Pascasarjana UIN Sunan Ampel Surabaya menyatakan bahwa pegawai di sana mempunyai beban tugas-tugas yang cukup banyak dengan tenaga kerja yang sedikit misalnya di bagian bendahara mereka ada tugas untuk mengelola keuangan dan ditambah lagi tugas diluar job description dari bendahara mereka juga membuat desain spanduk untuk acara diadakan perusahaan, perubahan negatif ini dapat mengakibatkan sikap atau perilaku pegawai menjadi berubah dan berdampak pada stres kerja yang dirasakan yang kemudian dikaitkan dengan niat 
untuk mogo kerja, hal ini juga berkaitan pada hasil tunjangan tambahan yang diberikan kurang membuat kepuasan kerja dan kesejahteraan psikologis pada pegawai bermasalah. Hasil studi ini diperkuat penelitian Martynowska et al. (2020).

\section{KESIMPULAN}

Berdasarkan hasil observasi serta analisa yang sudah dijabarkan sebelumnya, maka dapat diambil kesimpulan bahwa pertama, terdapat pengaruh negatif dan signifikan stres kerja terhadap kesejahteraan psikologis pada pegawai, yang berarti tingkat stres kerja pegawai yang semakin tinggi akan menurunkan kualitas kesejahteraan psikologis pegawai. Kedua, pengaruh positif dan signifikan kepuasan kerja atas kesejahteraan psikologis di pegawai, yang punya makna bahwa kenaikan kesejahteraan psikologis berbanding lurus dengan kepuasan kerja serta sebaliknya. Ketiga, stres kerja dan kepuasan kerja berpengaruh secara signifikan terhadap kesejahteraan psikologis.

Penelitian ini masih memiliki limitasi yaitu pada saat pengambilan data ke pegawai, sebagian besar pegawai bekerja di rumah atau yang disebut work from home (WFH) maka penyebaran kuesioner dilakukan secara online. Dari hasil tersebut disarankan untuk penelitian selanjutnya dapat melakukan penyebaran kuesioner dengan cara offline atau bertatap muka dengan pegawai. Penelitian selanjutnya juga direkomendasikan menggunakan indikator yang baru pada stres kerja yang dikemukkan oleh Bemana et al. (2013) di antaranya adalah beban kerja, konflik peran, ketidakjelasan peran dan tekanan kinerja; indikator kepuasan kerja dikemukkan oleh Robbins \& Timothy (2016) yakni gaji, pekerjaan itu sendiri, kesempatan promosi, supervisor, dan rekan kerja; dan indikator kesejahteraan psikologis dikemukkan oleh Parasurman \& Simmers (2001) yakni kepuasan kerja, kepuasan karier, kepuasan keluarga, dan stres kehidupan.

\section{DAFTAR PUSTAKA}

Anggarwati, P. I., \& Thamrin, W. P. (2020). Work Family-Conflict dan Psychological Well-Being pada Ibu Bekerja. Jurnal Psikologi Universitas Gunadarma, 12(2), 200-212. https://doi.org/10.35760/psi.2019.v12i2.2444

Anggraeni, T. P., \& Jannah, M. (2014). Hubungan antara Psychological Well-Being dan Kepribadian Hardiness dengan Stres pada Petugas Port Security. Character: Jurnal Penelitian Psikologi, 3(2), $1-5$.

As'ad, M. (2015). Seri Ilmu SDM: Psikologi Industri. Edisi Keempat. Yogyakarta: Liberty.

Bemana, S., Moradi, H., Ghasemi, M., Taghavi, S. M., \& Ghayoor, A. H. (2013). The Relationship among Job Stress and Job Satisfaction in Municipality Personnel in Iran. World Applied Sciences Journal, 22(2), 233-238. https://doi.org/10.5829/idosi.wasj.2013.22.02.3640

Cardak, M. (2013). Psychological Well-Being and Internet Addiction Among University Students. TOJET: The Turkish Online Journal of Educational Technology, 12(3), 134-141.

Chitra, T., \& Karunanidhi, S. (2021). The impact of Resilience Training on Occupational Stress, Resilience, Job Satisfaction, and Psychological Well-Being of Female Police Officers. Journal of Police and Criminal Psychology, 36(1), 8-23. https://doi.org/10.1007/s11896-018-9294-9

Devonish, D. (2016). Emotional Intelligence and Job Performance: The Role of Psychological WellBeing. International Journal of Workplace Health Management, 9(4), 428-442. https://doi.org/10.1108/IJWHM-04-2016-0031

Drakopoulos, S. A., \& Grimani, K. (2015). The Effect of Pay Cuts on Psychological Well-Being and $\begin{array}{llll}\text { Job Satisfaction. Nova } & \text { Science Publishers, 61(5), }\end{array}$ 
Fellia Sakti Dewi Washinta \& Hafid Kholidi Hadi. Pengaruh Job Stress dan Job Satisfaction terhadap Psychological Well-Being

https://doi.org/10.13140/2.1.3319.0722

Fattah, H. (2017). Kepuasan Kerja dan Kinerja Pegawai. Yogyakarta: Penerbit Elmatera.

Ghozali, I. (2016). Aplikasi Analisis Multivariete dengan Program IBM SPSS 23. Semarang: Badan Penerbit Universitas Diponegoro.

Hamaideh S. H. (2011). Stressors and Reactions to Stressors Among University Students. International Journal of Social Psychiatry, 57(1), 69-80. http://www.sagepub.co.uk/journals

Hasibuan, M. (2003). Manajemen Sumber Daya Manusia. Jakarta: Bumi Aksara.

Issom, F. L., \& Raisata, M. (2017). Pengaruh Stres Situasi Kerja Terhadap Psychological Well-Being Pada Guru Honorer Madrasah Ibtidaiyah di Kota Tangerang. Perspektif Ilmu Pendidikan, 31(1), 61-67. https://doi.org/10.21009/PIP.311.8

Jasmani binti Mohd Yunus, Jumaat bin Mahajar, A. (2011). Stress and Psychological Well-Being of Government Officers in Malaysia. The Journal of Human Resource and Adult Learning, 7(2), 40-50.

Karima, R. F., \& Baidun, A. (2019). Pengaruh Psychological Capital dan Kepuasan Kerja terhadap Psychological Well-Being pada Petugas Pemadam Kebakaran. TAZKIYA: Journal of Psychology, 2(2), 171-182. https://doi.org/10.15408/tazkiya.v2i2.10768

Lantara, D., \& Nusran, M. (2019). Dunia Industri: Prespektif Tenaga Kerja. Makassar: Nas Media Pustaka.

Lee, Mi Young, \& Kim, K. (2012). Influence of Head Nurses' Transformational Leadership on Staff Nurse's Psychological Well-Being, Stress and Somatization (Focused on the Mediating Effect of Positive Psychological Capital). Journal of Korean Academy of Nursing Administration, 12(2), $166-175$.

Leong, J. J., \& Malek, M. D. A. (2020). Kesan Sumber Stres Kerja ke Atas Kesejahteraan Psikologi Anggota Penguat Kuasa. Cross Cultural Management: An International Journal, 17(7), 31-48. https://ejournal.ukm.my/ebangi/article/view/41591

Malek, M. D. A., Mearns K., \& F. R. (2010). Stress and Psychological Well-Being in UK and Malaysian Fire Fighters. Cross Cultural Management: An International Journal, 17(1), 50-61.

Martynowska, K., Korulczyk, T., Janusz, P., \& Id, M. (2020). Perceived Stress and Well-Being of Polish migrants in the UK after Brexit Vote. PLoS ONE, 15(7), 1-15. https://doi.org/10.1371/journal.pone.0236168

Muniandy, J. (2017). An Investigation on English Teachers' Psychological Well-Being and Their Job Satisfaction. International Journal of Novel Research in Humanity and Social Sciences, 4(2), 20 31. www.noveltyjournals.com

Nandoliya, D. H. G. (2017). Psychological Well-Being and Job Satisfaction of Government and Private Aided Higher Secondary School Teachers. Journal of Multidisciplinary Subjects (PeerReviewed), 11(1), 58-68.

Nunes Machado de Oliveira Santos, J., Fontes De La Longuiniere, A. C., Sales Vieira, S. N., Passos Souza Amaral, A., de Jesus Cruz Sanches, G., \& Benemérita Alves Vilela, A. (2019). Occupational Stress: the Exposure of an Emergency Unit Nursing Team. Revista de Pesquisa: Cuidado e Fundamental, 11(2), 455-463. 
Nzenweaku, J. U., Akinola, J., \& O. C. (2020). Stress and Social Support as Predictors of Psychological Well-Being of Working Mothers in Nsukka, Enugu State, Nigeria. Journal of Professional Counselling and Psychotherapy Research (JPCPR), 3(1), 127-139.

Oktaviani, Z. A., \& Suprapti, V. (2021). Pengaruh Psychological Well-Being terhadap Stres Akademik Siswa SMA di Masa Covid-19. Buletin Riset Psikologi Dan Kesehatan Mental, 1(1), 965-975. http://dx.doi.org/10.20473/brpkm.v1i1.27667

Parasurman, S., \& Simmers, C. A. (2001). Type of Employment, Work-Family Conflict and WellBeing: A comparative study. Journal of Organizational Behavior, 22(5), 551-568. https://doi.org/10.1002/job.102

Prilianti, R., Sutarto, J., \& Prihatin, T. (2021). Did Transformational Leadership, Trust, Psychological Well-Beingand Organizational Culture Influence Organizational Commitment? Evidence from Government Education and Training Centers in Semarang. European Journal of Molecular \& Clinical Medicine, 7(1), 4245-4262.

Quilim, N. A., Taroreh, R., \& Nelwan, O. (2016). Pengaruh Kesejahteraan Psikologis, Job Enrichment dan Job Enlargment terhadap Kepuasan Kerja pada PT. Bank Mandiri (Persero) TBK Cabang Ternate Maluku Utara. Jurnal EMBA, 4(1), 1356-1368. https://doi.org/10.35794/emba.v4il.12356

Ramadhani, T., Djunaidi, Sismiati, A. (2016). Kesejahteraan Psikologis (Psychological Well-Being) Siswa yang Orang Tuanya Bercerai (Studi Deskripsif yang dilakukan pada Siswa di SMK Negeri 26 Pembangunan Jakarta). Insight: Jurnal Bimbingan Konseling, 5(1), 108-115.

Robbins, S. P., \& Judge, T. A. (2018). Essentials of Organizational Behavior. United States: Pearson Education.

Robbins, S. P., \& Timothy, A. J. (2016). Perilaku Organisasi Edisi 16. Jakarta: Salemba Empat.

Robbins, S. P. (2002). Prinsip-Prinsip Perilaku Organisasi (Edisi 5). Jakarta: Penerbit Erlangga.

Ryff, C. D. (2014). Psychological Well-Being Revisited: Advances in the Science and Practice of Eudaimonia. Journal of Psychotherapy and Psychosomatic, 83, 10-28. https://doi.org/10.1159/000353263

Sirait, D. M. F. (2020). Pengaruh Kecerdasan Emosional terhadap Psychological Well-being pada Karyawan PT. PLN (Persero) Kantor Wilayah Sumatera Utara. Jurnal Ilmu Psikologi. 8(2), 17 29.

Soteriades, E. S., Psalta, L., Leka, S., \& Spanoudis, G. (2019). Occupational Stress and Musculoskeletal Symptoms in Firefighters. International Journal of Occupational Medicine and Environmental Health, 32(3), 341-352. https://doi.org/10.13075/ijomeh.1896.01268

Spector, P. E. (1997). Job Satisfaction: Application. Assessment, Causes, and Consequences. California: Sage Publications.

Sugiyono. (2018). Metode Penelitian Kuantitatif, Kualitatif dan R\&B. Bandung: Alfabeta.

Susilo Martoyo. (2007). Manajemen Sumber Daya Manusia. Yogyakarta: BPFE-Yogyakarta.

Tasema, J. K. (2018). Hubungan Antara Psychological Well Being dan Kepuasan Kerja pada Karyawan 
Fellia Sakti Dewi Washinta \& Hafid Kholidi Hadi. Pengaruh Job Stress dan Job Satisfaction terhadap Psychological Well-Being

di Kantor X. Jurnal Maneksi, 7(1), 39-46. https://doi.org/10.31959/jm.v7i1.84.g40

Vanchapo, A. R. (2020). Beban Kerja dan Stres Kerja. Bandung: PT Remaja Roesdakarya.

Yücel, İ. (2016). Investigating the Psychological Well-Being and Job Satisfaction Levels in Different $\begin{array}{llll}\text { Occupations. International Education } & \text { Studies, } & \text { 9(12), } & \text { 194-205. }\end{array}$ https://doi.org/10.5539/ies.v9n12p194 